\title{
Evaluating the Impacts of Customer Experience on Purchase Intention
}

\author{
Amir Nasermoadeli ${ }^{1}$, Kwek Choon Ling ${ }^{1} \&$ Farshad Maghnati ${ }^{1}$ \\ ${ }^{1}$ Faculty of Business and Information Science, UCSI University, Kuala Lumpur, Malaysia \\ Correspondence: Kwek Choon Ling, Faculty of Business and Information Science, UCSI University, No.1, Jalan \\ Menara Gading, UCSI Heights, 56000 Kuala Lumpur, Malaysia. Tel: 60-1-6688-6248. E-mail: \\ kwekcl@ucsi.edu.my
}

\author{
Received: September 12, 2012 Accepted: January 28, 2013 Online Published: February 27, 2013 \\ doi:10.5539/ijbm.v8n6p128 \\ URL: http://dx.doi.org/10.5539/ijbm.v8n6p128
}

\begin{abstract}
With the emerging of experience economy, more and more scholars start to put more effort in exploring the knowledge of experiential marketing. As one of the core concepts in the experiential marketing, customer experience has been used as a base to predict the customer purchase intention. The purpose of this research paper is to discover the relationships between customer experience (including sensory experience, emotional experience and social experience) and purchase intention. A total of 330 respondents being investigated in this research. The results from the study concluded that only the emotional experience and social experience have significant positive impacts on the purchase intention; the sensory experience positively influences the emotional experience; the emotional experience is positively related to the social experience; the sensory experience has positive impact on the social experience; there is a positive relationship between the sensory experience and purchase intention, mediated by emotional experience; there is a positive relationship between the emotional experience and purchase intention, mediated by social experience; and lastly there is a positive relationship between the sensory experience and purchase intention, mediated by social experience.
\end{abstract}

Keywords: sensory experience, emotional experience, social experience, purchase intention

\section{Introduction}

The concept of customer experience was intimately conceived in the mid-1980s when Holbrook and Hirschman (1982) introduced a new experiential approach into the consumer behaviour domain. The concept of customer experience seems to create a common understanding among many experts, professionals and service scientists in discussing the topic of customer experience. Current extant literature concluded that the customer experience may act as a new weapon in the competition, especially in the new horizon of experience economy (Pine and Gilmore, 1999; Shaw and Ivens, 2002; Meyer and Schwager, 2007). Verhoef (2009, p.31) described customer experience as "the customer's cognitive, affective, emotional, social and physical responses" to the product and service providers. Schmitt (1999) argued that the level of customer's sense, feel, think, act and relate do influence the customer experience. Based on the extant literature, there is a lacking of studies in investigating both the direct and mediating relationships between the dimensions of customer experience (consisting of sensory, emotional and social experience) and purchase intention. Thus, this research would like to investigate both the direct and mediating relationships between the dimensions of customer experience (consisting of sensory experience, emotional experience and social experience) and purchase intention.

\section{Literature Review}

\subsection{Purchase Intention}

Turney and Littman (2003) asserted that intention to buy is the buyer's prediction of which company he will select to buy. Intention to buy may be recognized as a reflection of real purchase behaviour. The greater the purchase intention is, the greater a consumer's desire is to buy a product (Schiffman and Kanuk, 2000). Chi, et al (2009) and Laroche and Zhou (1996) claimed that marketing endorser's visibility rate can change consumer's personal preference and mind-set and ultimately influence consumer purchase intention. Besides, Fournier (1998) discovered that if a brand provides product features that meets consumer's need, then consumer will form a mental organization in related to the importance of the company toward him or her; subsequently, the consumer will subjectively form his or her relationship with the brand and raise his or her purchase intention accordingly. Monroe and Krishnan (1985) and Zeithaml (1988) argued that both recognized value and excellent offered by the 
firms will affect individual purchase intention, and the more recognized value and excellent being offered, the greater purchase intention is.

\subsection{Customer Experience}

Customer experience is a multi-facet concept. Collins English Dictionary (2011) described experience as "a particular incident, feeling, etc, that a person has undergone". Whereas, Schmitt (1999) stated that "experiences provide sensory, emotional, cognitive, behavioural and relational values that replace functional values." Gentile, Spiller and Noci (2007, p.397) asserted that "the customer experience comes from a set of relationships between a customer and an item or service, a company, or part of its company, which cause a response. This experience is stringently personal and indicates the consumer engagement at different amounts (rational, emotional, sensorial, physical, and spiritual)". Gupta and Vajic (2000) provide a more comprehensive definition of customer experience and they argued that "an experience occurs when a customer has any sensation or knowledge acquisition resulting from some level of interaction with different elements of a context created by the service provider". Schmitt (1999) proposed three dimensions of customer experience, including sensory experience, emotional experience, and social experience. The following paragraph will elaborate sensory experience, emotional experience and social experience in details.

\subsection{Sensory Experience}

Schmitt (1999) defined sensory experience as "the aesthetics and sensory perceptions about the shopping environment, atmosphere, products and service". According to Hulten, Broweus and Dijk (2009), each of the five human senses (including smell, sound, sight, taste, and touch) do contribute to the establishment of an experience and all the senses interact together will form the foundation of "sensory experience". Vargo and Lusch (2004) argued that the consumers sensory experience can cause to what the creators call "the experience logic", so this experience logic posits the person's personal sensory experience in the brain and the experience judgement that created from the personal sensory experience may enable the individual to develop behavioural, emotional, cognitive, relational, or symbolic values toward the products or services offered. Based on this argument, the experience logic merges emotional and rational elements in the brain to assist in the sensory experience of a brand. Gobe (2001) took a different perspective in illustrating the sensory experience. Gobe (2001) argued that the greatest objective for the person's sensory experience is to help individual to promote identification creation, self-fulfillment and self-image. This makes the sensory experience in itself a service to customers. Sensory experience has been used in the sense marketing. Lindstorm (2005) argued that companies can use a sensory marketing technique with the aim of gaining the five senses and offering sensory experience.

\subsection{Emotional Experience}

Schmitt (1999) referred emotional experience as "the moods and emotions generating during the shopping trip". Yang and He (2011) asserted that the emotional experience will generate effective experience, ranging from a little positive moods and progress to a strong emotion of joy and satisfaction that attached to a brand. Friman (2004) had discovered that the degree of experiencing critical incidents did create impact on emotional reactions. LeDoux (1996) described emotional experience as how a company is able to create emotions and how it can be explained based on response, central, cognitive, and arousal theories. Roos (1999) argued that customers who are experiencing negative emotional responses tend to have strong brand switching behaviour. In addition, "emotionally bonded customers tend to invest more in their relationships than customers lacking affective commitment" (Mattila, 2001). Fournier, (1998) and Arnould and Cost (1993) believed that the consumers' emotional connection with a company is more highly associated with their purchase intention in the near future. It is commonly recognized that customer experience and long-term personality intention are affected by the emotions that generated throughout the consumption periods of an assistance encounter (Oliver, 1997; Cronin et al, 2000; Barsky and Nash, 2002). Emotions do influence the attitude creation, therefore some of the extant literature suggested that emotions create significant impact in formatting and modifying approaches used by consumers to consume products and services (Hoyer and McInnis, 2001; Price, Arnould and Tierney, 1995).

\subsection{Social Experience}

Schmitt (1999) defined social experience as "the relationship with others and society". Schmitt (2003) argued that every social experience can create impacts toward individual in the socializing procedure through family, schooling, peer groups, and mass media. Each of these social impacts has the power to influence our thoughts, feelings and activities. For example, the association with the peer group allows individuals to obtain useful experience in creating social connections on their own and creating a sense of themselves (Macionis and Plummer, 1997). Beside peer group, the mass media --- television, radio, and newspapers do create great impacts on individuals via the socialization process (Olsen, 1993). Therefore, Griffiths (2003) argued that social 
experience can form individual skill to recognize appropriate multiplying and shoaling partners as well as affect the individual conduct in a behaviour way.

\subsection{Relationship between Customer Experience and Purchase Intention}

Igbaria, Guimaraes and Davis (1995) examined the results of customer experience within the structure of the customized Technological Acceptance Model and discovered that the customer experience creates immediate and oblique effect on purchase intention. Bellman, Loshe and Johnson (1999) also concluded that purchase intention is influenced by the levels of consumer experience. Yang and He (2011) asserted that experience does influence the customers' preferences, which then subsequently affect their purchase decision. Boyer and Hult (2006) performed a research on customer behavioural intentions for online purchasing utilizing data retrieved from the survey of over 2,100 customers and their findings pointed out that behavioural intention will be at variance based on customer experience level. Clearly, if the customers increase their positive shopping experience, then their chances of intention to purchase the products and services would be higher. Since the dimensions of consumer experience consist of sensory experience, emotional experience and social experience, this research paper would like to investigate and test the relationship between the dimensions of customer experience on purchase intention.

Yang and He (2011) elaborated the dimensions of customer experience (consisting of sensory experience, emotional experience and social experience) and they also illustrated theoretically how these dimensions of customer experience related to each other's. However, Yang and He (2011) empirically evaluated the direct impact of sensory experience, emotional experience and social experience on purchase intention (Yang and $\mathrm{He}$, 2011). There is a lacking of study in the Yang and He (2011) research to investigate the role of sensory experience, emotional experience and social experience in mediating the relationship between the dimensions of customer experience and purchase intention respectively. Consequently, this research paper seeks to identify and determine the direct and mediating relationships between the dimensions of customer experience and purchase intention through respective tested hypotheses.

\subsection{Hypotheses}

Based on the above literature review, the proposed conceptual framework was indicated in Figure 1 and the hypotheses were listed as follows:

H1: The sensory experience is positively related to the purchase intention.

$\mathrm{H} 2$ : The emotional experience is positively related to the purchase intention.

H3: The social experience is positively related to the purchase intention.

$\mathrm{H} 4$ : The sensory experience is positively related to the emotional experience.

H5: The emotional experience is positively related to the social experience.

H6: The sensory experience is positively related to the social experience.

H7: There is a positive relationship between the sensory experience and purchase intention, mediated by emotional experience.

H8: There is a positive relationship between the emotional experience and purchase intention, mediated by social experience.

H9: There is a positive relationship between the sensory experience and purchase intention, mediated by social experience.

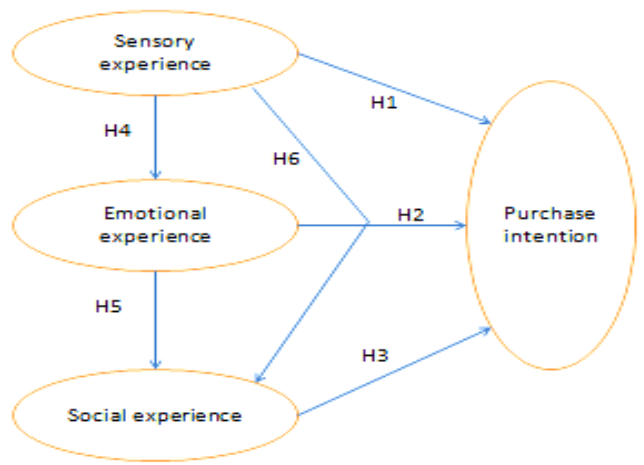

Figure 1. Proposed conceptual framework 


\section{Research Methodology}

\subsection{Research Design}

Descriptive research design was adopted in this research because of having clear hypotheses and literature review (Malhotra, 2004).

\subsection{Questionnaire Design}

Questionnaire was divided into two parts. Part A of the questionnaire elaborated the tested constructs (such as sensory experience, emotional experience, social experience and purchase intention) in the study. The questions in Part A asked the respondents' experiences in the process of going to a cinema and watching movie in the cinema. Part B of the questionnaire elaborated the respondents' profiles. The items of the questionnaire for the sensory experience, emotional experience, social experience and purchase intention were adopted from Yang and He (2011). A 5-point Likert scale anchored by "strongly disagree" (1) to "strongly agree" (5) was used as the attitude measurement for all the tested constructs (Yang and He, 2011).

\subsection{Sampling}

Existing full time business students in the private university that allocated in Kuala Lumpur (the capital city of Malaysia) will be treated as the target population. Cross sectional study was conducted in this research. The targeted sample size was 330 and judgmental sampling technique was adopted in this research.

\subsection{Administration of Survey}

Drop-off survey technique was used in this research. The respondents were given copies of self-administered survey questionnaire. The confidentiality and non-obligation (voluntary) aspects of participation in the survey were emphasized throughout the survey. 330 sets of questionnaires were disseminated and 320 sets of questionnaires were returned. From the tabulation, 20 sets of questionnaires were considered void because they were incomplete whereby over 25 percent of the questions in measuring the tested constructs were not answered (Sekaran, 2009). Therefore, a total of 300 usable sets of questionnaires (92 percent) were analysed by using the SPSS software version 20 .

\section{Research Results}

\subsection{Demographic Profile}

Based on the survey, the gender of total student respondents can be divided into male respondents ( 55 percent) and female respondents (45 percent). Most of the student respondents were between the ages of 21 to 25 (40.3 percent). The student respondents were mainly Chinese (56\%), followed by Indian (20\%), Malay (14\%) and others $(10 \%)$. The categories of the current highest academic level among the student respondents are mostly in bachelor degree $(63 \%)$, master degree $(25 \%)$ and doctoral degree $(12 \%)$.

\subsection{Reliability Test}

All the constructs were tested for the consistency reliability via the Cronbach alpha reliability analysis and the coefficient of 0.7 was used as a guideline in the analysis (Cavana, et al., 2001). The results in Table 1 indicated that the Cronbach alpha for all the tested constructs ranged from the lowest of 0.779 (Purchase Intention) to highest 0.948 (Emotional Experience). The analysis concluded that the measurement scales of the constructs were stable and consistent.

Table 1. Reliability test of variables

\begin{tabular}{cc}
\hline Variables & Reliability \\
\hline Sensory Experience & 0.818 \\
Emotional Experience & 0.948 \\
Social Experience & 0.876 \\
Purchase Intention & 0.779 \\
\hline
\end{tabular}

\subsection{Validity Test}

Constructs validity was adopted as validity measurement and factor analysis was used to measure the construct validity (Cavana et al., 2001). The details of the factor analysis were presented in Table 2. 
Table 2. Results of factor analysis

\begin{tabular}{llcccc}
\hline $\begin{array}{c}\text { Factor's } \\
\text { Name }\end{array}$ & \multicolumn{1}{c}{ Variable } & $\begin{array}{c}\text { Factor } \\
\text { Loading }\end{array}$ & Eigen-value & $\begin{array}{c}\text { Percentage of } \\
\text { Variance Explained }\end{array}$ & $\begin{array}{c}\text { Cronbach's Reliability } \\
\text { Coefficients }\end{array}$ \\
\hline Emotional & Happy & 0.800 & 11.172 & 17.721 & 0.948 \\
Experience & Pleased & 0.787 & & & \\
& Relax & 0.754 & & & \\
& Contended & 0.743 & & & \\
& Satisfied & 0.725 & & & \\
& Hopeful & 0.712 & & & \\
Social & Finding a sense of belonging & 0.738 & 1.608 & 10.373 & \\
Experience & Positioning social status & 0.701 & & & \\
& Promoting social status & 0.679 & & & \\
& Getting recognized & 0.633 & & & \\
Sensory & Arousing sensation & 0.851 & 1.241 & 10.240 & \\
Experience & Bringing interest & 0.789 & & & 0.779 \\
& Attractiveness & 0.644 & & & \\
& Being worthwhile & 0.633 & & & \\
Purchase & Recommending others to buy & 0.785 & 1.069 & & \\
Intention & Buying for one's self & 0.777 & & & \\
& Buying for family and friends & 0.753 & & & \\
\hline
\end{tabular}

Note: KMO Measure of Sampling Adequacy $=0.935 ; \mathrm{p}=0.000(\mathrm{p}<0.05) ; \mathrm{df}=325$

Cumulative Percentage Rotation Sums of Squared Loadings $=71.988$

Based on the output shown, factor analysis was appropriate because the value of Kaiser-Meyer-Olkin (KMO) was 0.935 (between 0.5 and 1.0) and the statistical test for Bartlett test of sphericity was significant ( $\mathrm{p}=0.000$; d.f. $=325$ ) for all the correlations within a correlation matrix (at least for some of the constructs). Based on the principal components analysis and VARIMAX procedure in orthogonal rotation, the results also showed that the Eigenvalues for all the constructs were greater than 1.0, ranging from the lowest 1.069 (Purchase Intention) to the highest of 11.172 (Emotional Experience). In terms of convergent validity, the factor loadings for all items within a construct were more than 0.50 . Discriminant validity indicated that all items were allocated according to the different constructs. Therefore, the items were not overlapping and they supported the respective constructs.

\subsection{Inferential Analysis}

Regression analysis was conducted in the inferential analysis to testify the hypothesized relationships for the respective hypotheses.

\subsubsection{Bivariate Regression Analysis}

The bivariate regression "is a procedure for deriving a mathematical relationship in the form of an equation, between a single metric dependent or criterion variable and a single metric independent or predictor variable" (Hair et al., 2006; Malhotra et al., 2006, p.692). Bivariate regression analysis was performed to test the fourth hypothesis (H4). The result of the bivariate regression analysis was presented in Table 3.

Table 3. Results of bivariate regression analysis for this research (H4)

\begin{tabular}{cccc}
\hline Variables & Unstandardized Beta Coefficients & t-value & Significant \\
\hline Sensory experience & 1.368 & 10.208 & 0.000 \\
\hline
\end{tabular}

Notes: Dependent variable: Sensory experience

Independent variables: Emotional experience

$\mathrm{R}=50.9$ percent; $\mathrm{R}$ Square $=25.9$ percent; Adjusted $\mathrm{R}$ Square $=25.7$ percent; $\mathrm{F}=104.202 ; \mathrm{P}=0.0001(\mathrm{p}<0.05)$

The $p$ value of the Sensory Experience $(p=0.000)$ is less than the alpha value of 0.05 . The value of the 
unstandardized beta coefficient is 1.368 . Therefore, the research concludes that Sensory Experience is positively related to the Emotional Experience. Hypothesis 4 (H4) is supported. The result also indicated that the change of Emotional Experience is explained 25.9 percent by Sensory Experience.

\subsubsection{Multiple Regression Analysis (H1, H2 and H3)}

Multiple regression analysis is the appropriate technique to analyze the linear relationship between a dependent variable and multiple independent variables by estimating coefficients for the equation of a straight line (Hair et al. 2006). Multiple regression analysis will be performed to test three hypotheses (H1, H2 and H3) in this research.

The result of the multiple regression analysis for hypothesis 1 was presented in Table 4 .

Table 4. Results of multiple regression analysis for this research (H1, H2 and H3)

\begin{tabular}{lccc}
\hline \multicolumn{1}{c}{ Variables } & Unstandardized Beta Coefficients & t-value & Significant \\
\hline Sensory experience & 0.056 & 1.699 & 0.101 \\
Emotional experience & 0.066 & 4.022 & 0.000 \\
Social experience & 0.147 & 2.959 & 0.005 \\
\hline
\end{tabular}

Notes: Dependent variable: purchase intention

Independent variables: three factors representing the dimensions of customer experience

$\mathrm{R}=54.4$ percent; $\mathrm{R}$ Square $=29.6$ percent; Adjusted $\mathrm{R}$ Square $=28.9$ percent $\mathrm{F}=41.429 ; \mathrm{P}=0.0001(\mathrm{p}<0.05)$

The $\mathrm{p}$ value of the Sensory Experience $(\mathrm{p}=0.101)$ is more than alpha value of 0.05 . Therefore, the research concludes that Sensory Experience is not positively related to the Purchase Intention. Thus, hypothesis 1(H1) is not supported.

The result of the multiple regression analysis for hypothesis 2 was presented in Table 4 . The $\mathrm{p}$ value of the Emotional Experience $(\mathrm{p}=0.000)$ is less than the alpha value of 0.05 . The value of the unstandardized beta coefficient is 0.066 . Therefore, the research concludes that Emotional Experience is positively related to the purchase intention. Thus, hypothesis 2 (H2) is supported.

The result of the multiple regression analysis for hypothesis 3 was presented in Table 4 . The p value of the Social Experience $(\mathrm{p}=0.005)$ is less than the alpha value of 0.05 . The value of the unstandardized beta coefficient is 0.147. Therefore, the research concludes that Social Experience is positively related to the Purchase Intention. Thus, hypothesis $3(\mathrm{H} 3)$ is supported.

In conclusion, the values of unstandardized beta coefficient among the significant independent variables tested in the hypotheses ranged from the weakest relationship of 0.067 (emotional experience and purchase intention) to the strongest relationship of 0.140 (between social experience and purchase intention). It may conclude that the social experience is the most powerful antecedent in affecting the purchase intention. The change of purchase intention is explained $29.6 \%$ by emotional experience and social experience.

4.4.3 Multiple Regression Analysis (H5 and H6)

The result of the multiple regression analysis for the hypothesis 5 was presented in Table 5 .

Table 5. Results of multiple regression analysis for this research (H5 \& H6)

\begin{tabular}{lccc}
\hline \multicolumn{1}{c}{ Variables } & Unstandardized Beta Coefficients & t-value & Significant \\
\hline Sensory experience & 0.135 & 3.241 & 0.001 \\
Emotional experience & 0.220 & 15.185 & 0.000 \\
\hline
\end{tabular}

Notes: Dependent variable: social experience

Independent variables: two factors representing dimensions of customer experience

$\mathrm{R}=75.9$ percent; $\mathrm{R}$ Square $=57.6$ percent; Adjusted $\mathrm{R}$ Square $=57.1$ percent; $\mathrm{F}=133.880 ; \mathrm{P}=0.0001(\mathrm{p}<0.05)$

The $\mathrm{p}$ value of the emotional experience $(\mathrm{p}=0.000)$ is less than the alpha value of 0.05 . The value of unstandardized beta coefficient is 0.220 . Therefore, the research concludes that emotional experience is 
positively related to the social experience. Hypothesis 5 (H5) is supported.

The result of the multiple regression analysis for the hypothesis 6 was presented in Table 5. The $p$ value of the sensory experience $(\mathrm{p}=0.001)$ is less than the alpha value of 0.05 . The value of unstandardized beta coefficient is 0.135 . Therefore, the research concludes that sensory experience is positively related to the social experience. Hypothesis 6 (H6) is supported.

In conclusion, the values of unstandardized beta coefficient among the independent variables tested in the hypotheses ranged from the weakest relationship of 0.135 (between sensory experience and social experience) to the strongest relationship of 0.220 (between emotional experience and social experience). It may conclude that the emotional experience is the most powerful antecedent in affecting the social experience. In conclusion, the change of social experience is explained $57.6 \%$ percent by a combination of two independent variables, including sensory experience and emotional experience.

\subsubsection{Mediated Regression Analysis (H7, H8 and H9)}

Mediational analysis is used to examine how two variables precede or cause a third variable (refer to dependent variable). According to Howitt and Cramer (2011a, p.330), the mediating variable may either partly explain the relation between the other predictor variables and the criterion variable or totally explain it. If it partly explains the relation, the other predictor will also partly explain the relation in the absence of additional mediating variables. If it totally explains the relation, the other predictor will only explain the relation through the mediating variable. In other words, the first variable will explain the relation indirectly rather than directly".

To test H7, H8 and H9, the three-step process recommended by Baron and Kenny (1986) was adopted in this study. According to this approach, three separate equations should be estimated: (1) The mediating variable is regressed on the independent variable; (2) The dependent variable is regressed on the independent variable; and (3) The dependent variable is simultaneously regressed on the dependent variable and the mediating variable.

Partial mediation is indicated when the independent variable's effect is reduced in magnitude, but is still significant when the mediator is controlled. Based on the recommendation of Baron and Kenny (1986), the results of the three-step process are presented in Table 6(a), 6(b) and 6 (c).

Table 6(a). Result of mediated multiple regression (mediator analysis) (H7)

\begin{tabular}{lccc}
\hline Independent Variable & Emotional Experience (Mediator) & \multicolumn{2}{c}{ Purchase Intention (Dependent Variable) } \\
\cline { 2 - 4 } & Model 1 & Model 2 & Model 3 \\
\hline Sensory Experience & $1.368^{*}$ & $0.205^{*}$ & $0.071^{*}$ \\
& $(\mathrm{p}=0.000)$ & $(\mathrm{p}=0.000)$ & $(\mathrm{p}=0.034)$ \\
& $\left(1^{\text {st }}\right.$ equation $)$ & $\left(2^{\text {nd }}\right.$ equation $)$ & $\left(3^{\text {rd }}\right.$ equation $)$ \\
Emotional Experience & & & $0.098^{*}$ \\
& & & $(\mathrm{p}=0.000)$ \\
& & & $\left(3^{\text {rd }}\right.$ equation $)$ \\
\hline
\end{tabular}

$* \bar{p}<0.05$

According to the finding from Table 6(a), sensory experience (independent variable) significantly affects the emotional experience (mediator) in the first equation; sensory experience (independent variable) significantly affects the purchase intention (dependent variable) in the second equation; both sensory experience (independent variable) and emotional experience (mediator) significantly affect purchase intention. Hypothesis 7 (H7) is supported because the beta value of sensory experience in the third equation (beta $=0.071$ ) is smaller than the beta value of sensory experience in the second equation (beta=0.205), diminishing by $0.134(0.205-0.071)$. In conclusion, emotional experience does act as a mediator in mediating the relationship between sensory experience and purchase intention. 
Table 6(b). Result of mediated multiple regression (mediator analysis) (H8)

\begin{tabular}{lccc}
\hline Independent & Social Experience (Mediator) & Purchase Intention (Dependent Variable) \\
\cline { 2 - 4 } & Model 1 & Model 2 & Model 3 \\
\hline Emotional & $0.244^{*}$ & $0.111^{*}$ & $0.074^{*}$ \\
Experience & $(\mathrm{p}=0.000)$ & $(\mathrm{p}=0.000)$ & $(\mathrm{p}=0.034)$ \\
& $\left(1^{\text {st }}\right.$ equation $)$ & $\left(2^{\text {nd }}\right.$ equation $)$ & $\left(3^{\text {rd }}\right.$ equation $)$ \\
Social & & & $0.153^{*}$ \\
Experience & & $(\mathrm{p}=0.002)$ \\
& & $\left(3^{\text {rd }}\right.$ equation $)$ \\
\hline .05 & &
\end{tabular}

$* \mathrm{p}<0 . \overline{05}$

According to the finding from Table 6(b), emotional experience (independent variable) significantly affects the social experience (mediator) in the first equation; emotional experience (independent variable) significantly affect the purchase intention (dependent variable) in the second equation; both emotional experience (independent variable) and social experience (mediator) significantly affect purchase intention. Hypothesis 8 (H8) is supported because the beta value of emotional experience in the third equation (beta $=0.074$ ) is smaller than the beta value of emotional experience in the second equation (beta=0.111), diminishing by 0.037 (0.111-0.074). In conclusion, social experience does act as a mediator in mediating the relationship between emotional experience and purchase intention.

Table 6(c). Result of mediated multiple regression (mediator analysis) (H9)

\begin{tabular}{lccc}
\hline Independent & Social Experience (Mediator) & Purchase Intention (Dependent Variable) \\
\cline { 2 - 4 } & Model 1 & Model 2 & Model 3 \\
\hline Sensory & $0.419^{*}$ & $0.205^{*}$ & $0.090^{*}$ \\
Experience & $(\mathrm{p}=0.000)$ & $(\mathrm{p}=0.000)$ & $(\mathrm{p}=0.007)$ \\
& $\left(1^{\text {st }}\right.$ equation $)$ & $\left(2^{\text {nd }}\right.$ equation $)$ & $\left(3^{\text {rd }}\right.$ equation $)$ \\
Social & & & $0.274^{*}$ \\
Experience & & $(\mathrm{p}=0.000)$ \\
& & $\left(3^{\text {rd }}\right.$ equation $)$ \\
\hline
\end{tabular}

$* \mathrm{p}<0.05$

According to the finding from Table 6(c), sensory experience (independent variable) significantly affects the social experience (mediator) in the first equation; sensory experience (independent variable) significantly affects the purchase intention (dependent variable) in the second equation; both sensory experience (independent variable) and social experience (mediator) significantly affect purchase intention. Hypothesis 9 (H9) is supported because the beta value of sensory experience in the third equation (beta $=0.090$ ) is smaller than the beta value of sensory experience in the second equation (beta=0.205), diminishing by $0.115(0.205-0.090)$. In conclusion, social experience does act as a mediator in mediating the relationship between sensory experience and purchase intention.

\section{Conclusion}

\subsection{Conclusion of Hypotheses}

The findings from this research confirm that only emotional experience and social experience are positively related to the purchase intention. In addition, the research findings also conclude the interaction relationships between the dimensions of the customer experience: (1) the sensory experience is positively related to the emotional experience; (2) the emotional experience is positively related to the social experience; and (3) the sensory experience is positively related to the social experience. Lastly, the research findings also assert that: (1) there is a positive relationship between the sensory experience and purchase intention, mediated by emotional 
experience; (2) there is a positive relationship between the emotional experience and purchase intention, mediated by social experience; and (3) there is a positive relationship between the sensory experience and purchase intention, mediated by social experience.

\subsection{Implications of Research Findings-Theoretical Implications}

According to the extant literature, most of the scholars only illustrate the dimensions of customer experience in detail (ie., sensory experience, emotional experience and social experience) and there is a lack of study to evaluate the impacts of the dimensions of customer experience toward purchase intention in the Malaysia contact. This research has closed this gap and confirms that the dimensions of customer experience (only emotional experience and social experience) do impact on purchase intention.

In addition, the prior study doesn't provide conclusive empirical result in the extant literature to point out the integrated relationships between sensory experience, emotional experience and social experience. Through this research, the research has covered this gap and reconfirms that there are integrated relationships among sensory experience, emotional experience and social experience.

Besides, there is a lack of study in the present literature review to explore the role of mediator in mediating the relationships between the dimensions of customer experience (ie., sensory experience, emotional experience and social experience) and the purchase intention. Through this research, the research has indicated this gap and reconfirms that the relationships between the dimensions of customer experience and purchase intention mediated by emotional experience and social experience respectively.

\subsection{Managerial Implications}

The research findings provide some advices for the industry players in drafting various managerial strategies to increase the purchase intention, by emphasizing the different perspectives of customer experience, especially emotional experience and social experience. In addition, the research findings provide certain approaches to the industry players how to modify the customer experience (such as sensory experience, emotional experience and social experience) in the strategy planning because there are integrated relationships among sensory experience, emotional experience and social experience.

\subsection{Limitations of This Research}

Although the research findings add on additional knowledge to the current literature, these findings must be read with certain limitations. The adoption of cross-sectional data may not able to explain the customer experience according to the observed changes in pattern and the causality of the purchase intention across a long period of time (Easterby-Smith, Thorpe and Lowe, 2003, p.45). The adoption of judgemental sampling method in this research has also limited the generalizable of the research findings.

\subsection{Recommendations for Further Research}

Based on the current research limitations, a few recommendations are provided for the future research. Due to the limitation of cross-sectional study, longitudinal studies, which repeatedly compute the same sample units of a population over a period of time is suggested to be accepted in the prospect study (Burns \& Bush, 2003). According to the limitation of generalization, it is suggested to assume probability sampling technique in the future study for the reason to ornamental the validity and generality of the research findings.

\section{References}

Arnould, E. A. P., \& Cost, L. (1993). River magic: Extraordinary experiences and the extended service encounter. Journal of Consumer Research, 20(1), 24-45. http://dx.doi.org/10.1086/209331

Baron, R. M., \& Kenny, D. A. (1986). The moderator-mediator variable distinction in social psychological research: Conceptual, strategic, and statistical considerations. Journal of Personality \& Social Psychology, 51, 1173-1182. http://dx.doi.org/10.1037/0022-3514.51.6.1173

Barsky, J., \& Nash, L. (2002). Evoking emotion: Affective keys to hotel loyalty. Cornell Hotel and Restaurant Administration Quarterly, 43(1), 39-46. http://dx.doi.org/10.1016/S0010-8804(02)80007-6

Bellman, S., Lohse, G. L., \& Johnson, E. J. (1999). Predictors of online buying behavior. Communication of the $A C M, 42$ (12), 32-38. http://dx.doi.org/10.1145/322796.322805

Boyer, K. K., \& Hult, G. (2006). Customer behavioral intentions for online purchase: An examination of fulfillment method and customer experience level. Journal of Operation Management, 24(2), 124-147. http://dx.doi.org/10.1016/j.jom.2005.04.002

Burns, A., \& Bush, R. (2003). Marketing research: Online research application. New Jersey: Prentice Hall 
Cavana, R. Y. M., Delahaye, B. L., \& Sekaran, U. (2001). Applied business changing information environment (2nd ed.). New York: McGraw-Hill.

Chi, H. K., Yeh, H. R., \& Huang, M. W. (2009). The influences of advertising endorser, brand image, brand equity, price promotion on purchase intention: The mediating effect of advertising endorser. The Journal of Global Business Management, 5(1), 224-233.

Collins English Dictionary. (2011). Collins English Dictionary (11th ed.). United Kingdom: Collins.

Cronin, J., Brady, M. K., \& Hult, G. T. M. (2000). Assessing the effects of quality, value, and customer satisfaction on consumer behavioral intentions in service environments. Journal of Retailing, 76(2), 193-218. http://dx.doi.org/10.1016/S0022-4359(00)00028-2

Desmet, P. (2002). Designing emotions. Doctoral Dissertation, Technische Universiteit Delft, Delft.

Easterby-Smith, M., Thorpe, R., \& Lowe, A. (2003). Management research: An introduction (2nd ed.). California: SAGE Publications.

Fournier, S. (1998). Consumers and their brands: Developing relationship theory in consumer research. Journal of Consumer Research, 24(4), 343-373. http://dx.doi.org/10.1086/209515

Friman, M. (2004). The structure of affective reactions to critical incidents. Journal of Economic Psychology, 25, 331-353. http://dx.doi.org/10.1016/S0167-4870(03)00012-6

Gentile, C., Spiller, N., \& Noci, G. (2007). How to sustain the customer experience: An overview of experience components that co-create value with the customer. European Management Journal, 25(5), 395-410. http://dx.doi.org/10.1016/j.emj.2007.08.005

Gobe, M. (2001). Emotional branding: the new paradigm for connecting brands to people. New York: Allworth.

Griffiths, S. W. (2003). Learned recognition of conspecifics by fishes. Fish Fisher, 4, 256-268. http://dx.doi.org/10.1046/j.1467-2979.2003.00129.x

Gupta, S., \& Vajic, M. (2000). The contextual and dialectical nature of experiences. In J. Fitzsimmons, M. Fitzsimmons (eds.), New service development - creating memorable experiences (pp. 33-51). Thousand Oaks, CA: Sage. http://dx.doi.org/10.4135/9781452205564.n2

Hair, J. F. J., Black, W. C., Babin, B. J., Anderson, R. E., \& Tatham, R. L. (2006). Multivariate data analysis. New Jersey: Pearson Education

Holbrook, M. B., \& Hirschman, E. C. (1982). The experiential aspects of consumption: consumer fantasy, feelings and fun. Journal of Consumer Research, 9(2), 132-140. http://dx.doi.org/10.1086/208906

Howitt, D., \& Cramer, D. (2011). Introduction to SPSS statistics in psychology: For version 19 and earlier (5th ed.). Essex: Pearson Education Limited.

Hoyer, W. D. A., \& McInnis, D. (2001). Consumer behavior. Boston, MA: Houghton Mifflin.

Hulten, B., Broweus, N., \& Van Dijk, M. (2009). Sensory marketing. Hamsphire, United Kingdom: Palgrave-Macmillan. http://dx.doi.org/10.1057/9780230237049

Igbaria, M., Guimaraes, T., \& Davis, G. B. (1995). Testing the determinants of microcomputer usage via a structural equation model. Journal of Management Information Systems, 11(4), 87-114.

Laroche, M. K. C., \& Zhou, L. (1996). Brand familiarity and confidence as determinants of purchase intention: an empirical test in a multiple brand context. Journal of Business Research, 37, 115-120. http://dx.doi.org/10.1016/0148-2963(96)00056-2

LeDoux, J. (1996). The emotional brain. New York: Simon \& Schuster.

Lindstorm, M. (2005). Brand sense: Build powerful brands through touch, taste, smell, slight and sound. New York: Free Press.

Macionis, J. J., \& Plummer, K. (1997). Sociology. New York: Prentice Hall.

Malhotra, N. K. (2004). Marketing research: An applied orientation (4th ed.). New Jersey: Prentice- Hall.

Malhotra, N., \& Peterson, M. (2006). Basic marketing research: A decision-making approach (2nd ed.). New Jersey: Prentice Hall.

Mattila, A. S. (2001). Emotional bonding and restaurant loyalty. Cornell Hotel and Restaurant Administration Quarterly, 42(6), 73-79. http://dx.doi.org/10.1016/S0010-8804(01)81012-0 
Meyer, C., \& Schwager, A. (2007). Understanding customer experience. Harvard Business Review, 2, 117-126.

Monroe, K. B., \& Krishnan, R. (1985). The effect of price on subjective product Evaluation. In J. Jacoby \& O. C. Jerry (Eds.), Perceived quality: How consumers view stores and merchandise (pp. 209-232). Lexington, M.A: Lexington Books.

Oliver, R. L. (1997). Satisfaction: A behavioural perspective on the consumer. London: McGraw-Hill.

Olsen. (1993). Impact of social network on cardiovascular mortality in middle aged Danish men. Epideniiol Community Health, 47(7), 176-180. http://dx.doi.org/10.1136/jech.47.3.176

Pine, B. J., \& Gilmore, J. H. (1999). The experience economy: Work is theatre and every business is a stage. Boston: Harvard Business School Press.

Price, L., Arnould, E., \& Tierney, P. (1995). Going to extremes: Managing service experiences and assessing provider performance. Journal of Marketing, 59(2), 83-97. http://dx.doi.org/10.2307/1252075

Roos, I. (1999). Switching processes in customer relationships. Journal of Service Research, 2(1), 376-393. http://dx.doi.org/10.1177/109467059921006

Schiffman, L. G., \& Kanuk, L. (2000). Consumer behavior. New Jersey: Prentice Hall.

Schmitt, B. H. (1999). Experiential marketing: How to get customers to sense, feel, think, act and relate to your company and brands. New York: Free Press.

Schmitt, B. H. (2003). Customer experience management: A revolutionary approach to connecting with your customer. Indianapolis: John Wiley \& Sons.

Sekaran, U. (2003). Research methods for business: A skill-building approach (4th ed.). New York: John Wiley $\&$ Sons.

Shaw, C., \& Ivens, J. (2002). Building great customer experiences. New York: MacMillan. http://dx.doi.org/10.1057/9780230554719

Turney, P. D., \& Littman, M. L. (2003). Measuring praise and criticism: Inference of semantic orientation from association. ACM Transportation Information System, 21(4), 315-346. http://dx.doi.org/10.1145/944012.944013

Vargo, S. L., \& Lusch, R. F. (2004). Evaluating to a new dominant logic for marketing. Journal of Marketing, 68(1), 1-17. http://dx.doi.org/10.1509/jmkg.68.1.1.24036

Verhoef, P. C. (2009). Customer experience creation: Determinants, dynamics and management strategies. Journal of Retailing, 85(1), 31-41. http://dx.doi.org/10.1016/j.jretai.2008.11.001

Zeithaml, V. A. (1988). Consumer perceptions of price, quality and value: A means-end model and synthesis of evidence. Journal of Marketing, 52, 2-22. http://dx.doi.org/10.2307/1251446

Zi-Ying, Y., \& Ling-Yun, H. (2011). Goal, customer experience and purchase intention in a retail context in China: An empirical study. African Journal of Business Management, 5(16), 6738-6746. 